\title{
Impact of water-level fluctuations on cyanobacterial blooms: options for management
}

\author{
Elisabeth S. Bakker $\cdot$ Sabine Hilt
}

Received: 9 January 2015/Accepted: 8 November 2015/Published online: 9 December 2015

(C) The Author(s) 2015. This article is published with open access at Springerlink.com

\begin{abstract}
Climate change can promote harmful cyanobacteria blooms in eutrophic waters through increased droughts or flooding. In this paper, we explore how water-level fluctuations affect the occurrence of cyanobacterial blooms, and based on the observations from case studies, we discuss the options and pitfalls to use water-level fluctuations for lake and reservoir management. A drawdown in summer causes an increase in retention time and increased water column nutrient concentrations and temperature of shallow water layers, which may lead to severe cyanobacterial blooms. This effect can potentially be counteracted by the positive response of submerged macrophytes, which compete for nutrients with cyanobacteria, with a higher chance of cyanobacterial blooms under eutrophic conditions. The balance between dominance by submerged macrophytes or
\end{abstract}

Guest editors: Petra M. Visser, Bas W. Ibelings, Jutta Fastner \& Myriam Bormans/Cyanobacterial blooms. Ecology, prevention, mitigation and control.

Handling Editor: Dr. Piet Spaak.

E. S. Bakker $(\bowtie)$

Department of Aquatic Ecology, Netherlands Institute of Ecology (NIOO-KNAW), Droevendaalsesteeg 10, 6708 PB Wageningen, The Netherlands

e-mail: 1.bakker@nioo.knaw.nl

S. Hilt

Leibniz Institute of Freshwater Ecology and Inland Fisheries, Müggelseedamm 301, 12587 Berlin, Germany cyanobacteria is temperature sensitive with stronger positive effects of drawdown as inhibition of cyanobacterial blooms expected in colder climates. Complete drying out reduces the amount of cyanobacteria in the water column after refilling, with lower water nutrient concentrations, lower fish biomass, lower abundance of cyanobacteria, higher transparency, and higher cover of submerged plants compared to lakes and reservoirs that did not dry out. Water-level rise as response to flooding has contrasting effects on the abundance of cyanobacteria depending on water quality. We conclude that waterlevel fluctuation management has potential to mitigate cyanobacterial blooms. However, the success will depend strongly on ecosystem properties, including morphometry, sediment type, water retention time, quality of inlet water, presence of submerged vegetation or propagules, abundance of fish, and climate.

Keywords Climate change - Cyanobacteria .

Drawdown · Flooding · Lake · Macrophyte . Phytoplankton

\section{Introduction}

Aquatic ecosystems are increasingly subject to warming as well as to alterations in rainfall patterns as a consequence of climate change (IPCC 2007). Climate models predict an increase in stochastic events such as 
unpredictable floods and droughts as well as a change in timing or duration of ice cover and snowmelt (IPCC 2007; Wantzen et al. 2008). As a consequence, shallow water bodies will be increasingly prone to prolonged droughts or flooding (Williamson et al. 2009). Particularly in the warmer climates, such as the Mediterranean, shallow water bodies may turn into ephemeral ones during multi-annual droughts (Beklioglu et al. 2007; Romo et al. 2013; Jeppesen et al. 2014).

Indeed, more variation in water levels in nonregulated systems is observed over the last decades (Adrian et al. 2009). Variability in lake hydrology, resulting in fluctuations in the water level, is a key factor affecting the functioning of lake ecosystems (Coops et al. 2003; Beklioglu et al. 2007; Jeppesen et al. 2014). One of the anticipated effects of climate change is the promotion of harmful cyanobacteria blooms in eutrophic waters (Paerl and Huisman 2009; Wagner and Adrian 2009). Increased droughts, increased water retention times, and increased temperatures are demonstrated to contribute to the dominance of cyanobacteria over other algae (Mooij et al. 2005; Paerl and Huisman 2008; O'Farrell et al. 2011; Kosten et al. 2012). In reservoirs, where water is typically removed for human water demand, the rate and extend of water-level fluctuations is mostly larger than in natural shallow lakes. Temporal variations of mean residence times occur not only at seasonal time scales, but also at shorter scales and are closely related to mixing and nutrient transport processes occurring within the reservoir (Rueda et al. 2006). In addition, extensive growth of riparian plants with subsequent nutrient release during rewetting (Kleeberg and Heidenreich 2004) or lacking recolonization of macrophytes after long periods of dry out may occur more frequently than in natural shallow lakes.

Overall, water-level fluctuations in both un-regulated as well as regulated waterbodies may be an important trigger for the promotion of cyanobacterial blooms. Rising of the water level in shallow lakes may result in a transition from the macrophyte-dominated state to the cyanobacteria-dominated state, due to a deterioration of the underwater light climate (Blindow et al. 1993; Havens et al. 2004). This may be of less relevance for deep, stratified lakes. In deep regulated lakes, changing water levels may result in a compressed vertical niche for macrophytes (Rørslett 1984) and consequently reduce their effects on cyanobacteria (Sachse et al. 2014).
On the contrary, lowering of the water table in shallow lakes may result in the opposite, where submerged macrophytes can benefit from the increased light availability and prevent the dominance of cyanobacteria. This knowledge is applied in lake restoration: The controlled lowering of the water level is one of the tools used to improve the water quality in degraded lakes (Coops and Hosper 2002). In deep natural lakes and reservoirs, macrophytes in the littoral zones may rather suffer from declining water levels. In general, more information became available on the effects of water-level fluctuations on the development of submerged and emergent vegetation over the last decade, but still little is known about the possibilities to use water-level fluctuations to mitigate cyanobacterial blooms.

\section{Proposed working mechanisms}

Using water-level fluctuations as a management tool to mitigate cyanobacterial blooms can potentially work through several mechanisms. First, there is a direct dilution effect of letting in water. When the outlet is open, this will reduce the water retention time, and the water body gets flushed out. This can lead to fluctuations in water level, but can also be performed while maintaining a stable water level. Lower retention times will reduce the nutrient concentration by reducing the impact of internal nutrient loading or from other external sources (Welch 1981). Furthermore, when cyanobacteria and algae are present, these will partly be washed out, depending on the flushing rate and the quality of the incoming water. The latter parameters determine the occurrence and the threshold levels for shifts between clear and turbid states (Hilt et al. 2011).

Flushing of shallow temperate lakes during the growing season of submerged macrophytes may only bring a turbid lake to a clear water state if the flushed water is relatively clear and the flushing rate is strong enough to induce the shift (Hilt et al. 2011). When the outlet is closed, extra (clearer) water will lead to a rise in water level, which dilutes the phytoplankton suspension, at least temporarily lowering the phytoplankton concentrations and algal blooms. These direct effects of increasing water volume or reducing the retention time on cyanobacterial abundance will be strongly influenced by the quality of the inlet water. 
However, when water-level fluctuations are applied as a management tool to improve the ecological conditions and water quality, water managers mostly aim for indirect effects to reduce cyanobacterial blooms. By managing the water level, they aim to restore a macrophyte-dominated clear water state in shallow water bodies (Coops and Hosper 2002). The water level is then regulated such to stimulate the establishment and growth of submerged and emergent macrophytes (Sarneel et al. 2014a). Once established, the macrophytes should then maintain the clear water state and inhibit cyanobacterial blooms (Jeppesen et al. 1998; Scheffer 1998; Kosten et al. 2009; Dong et al. 2014). Macrophytes can do so by capturing nutrients from the water column that are then no longer available for cyanobacterial growth (Van Donk and Van de Bund 2002; Hilt et al. 2010). This is especially true for non-rooted submerged macrophytes (Mjelde and Faafeng 1997). Many macrophyte species also excrete allelopathic substances which can inhibit cyanobacterial growth (Gross 2003; Hilt and Gross 2008). Cyanobacteria species and strains, however, may show a differential sensitivity towards macrophyte allelochemicals (Eigemann et al. 2013; Švanys et al. 2014), but existing studies on the sensitivity of toxic versus non-toxic strains of cyanobacteria were contradictory (Mulderij et al. 2005; Liu et al. 2007; Švanys et al. 2014). In addition, most studies on macrophyte allelopathic effects have been conducted with single cyanobacteria species, and species interactions may reverse the results (Chang et al. 2012). Conclusions concerning the in situ growth inhibition potential of macrophyte allelochemicals (e.g., Shao et al. 2013) should thus be drawn with caution.

Furthermore, macrophyte beds may serve as refugium for zooplankton against predation by fish resulting in a higher grazing pressure on phytoplankton (Schriver et al. 1995; Burks et al. 2001) and periphyton (Mahdy et al. 2015), harbour more macroinvertebrates, and promote piscivorous fish (Blindow et al. 2014 and references therein; Grutters et al. 2015). Together, these properties of macrophytes may reduce cyanobacterial abundance and increase water transparency (Van Donk and Van de Bund 2002; Bakker et al. 2010).

The timescale of direct and indirect measures to reduce cyanobacterial blooms by water-level management is different. Whereas direct measures are aimed at a short-term solution, the switch to a clear water state with macrophytes and without cyanobacterial blooms may require a longer time perspective. In this paper, we explore how water-level fluctuations affect the occurrence of cyanobacterial blooms and what lessons can be learned for the application of waterlevel management.

\section{Impact of water-level fluctuations on cyanobacteria: case studies}

Water-level management has been successfully used to stimulate macrophyte development (Coops et al. 2003; Van Geest et al. 2005; Holm and Clausen 2006; Ejankowski and Solis 2015), but is generally not aimed at reducing cyanobacterial blooms directly. However, water levels in lakes and reservoirs may fluctuate because of usage and extraction of water, drought, or flooding. To evaluate the effect of waterlevel fluctuations on cyanobacterial blooms, we therefore collected case studies of lakes and reservoirs where water levels fluctuated and where the water bodies contained high densities of cyanobacteria before or after water-level fluctuations. Furthermore, the studies had to report alterations in cyanobacterial abundance in relation to the waterlevel fluctuations.

We found 13 studies from a wide variety of habitats and ranges of water-level fluctuations from 12 different locations (Table 1). We realize that this list may not be complete, but we want to use these cases as examples to illustrate the important factors to take into account when applying water-level management with the aim to reduce or prevent cyanobacterial blooms.

Response of cyanobacteria to water-level fluctuations

Water-level fluctuations can affect the occurrence of cyanobacterial blooms (Table 1). A drawdown in summer by reducing flow rates causes an increase in retention time and an increase in water column nutrients both through the reduction of water volume as well as an increase in internal nutrient loading by release of nutrients from the sediment (Welch 1981). In deep lakes, water-level drawdown can disrupt the thermal stability of the water body and thus cause the elimination of the thermocline in summer. In shallow lakes, water drawdown can considerably decrease 


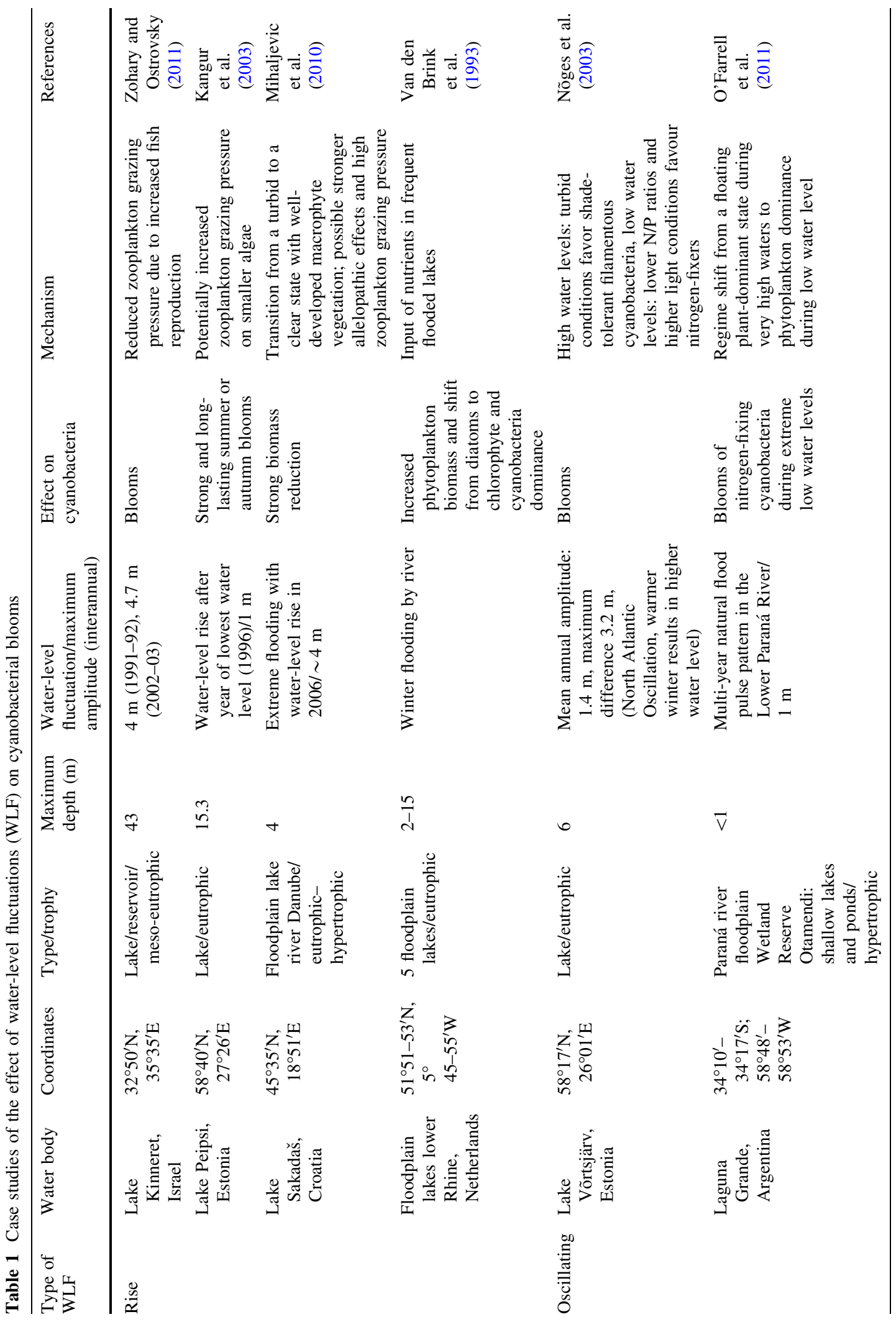




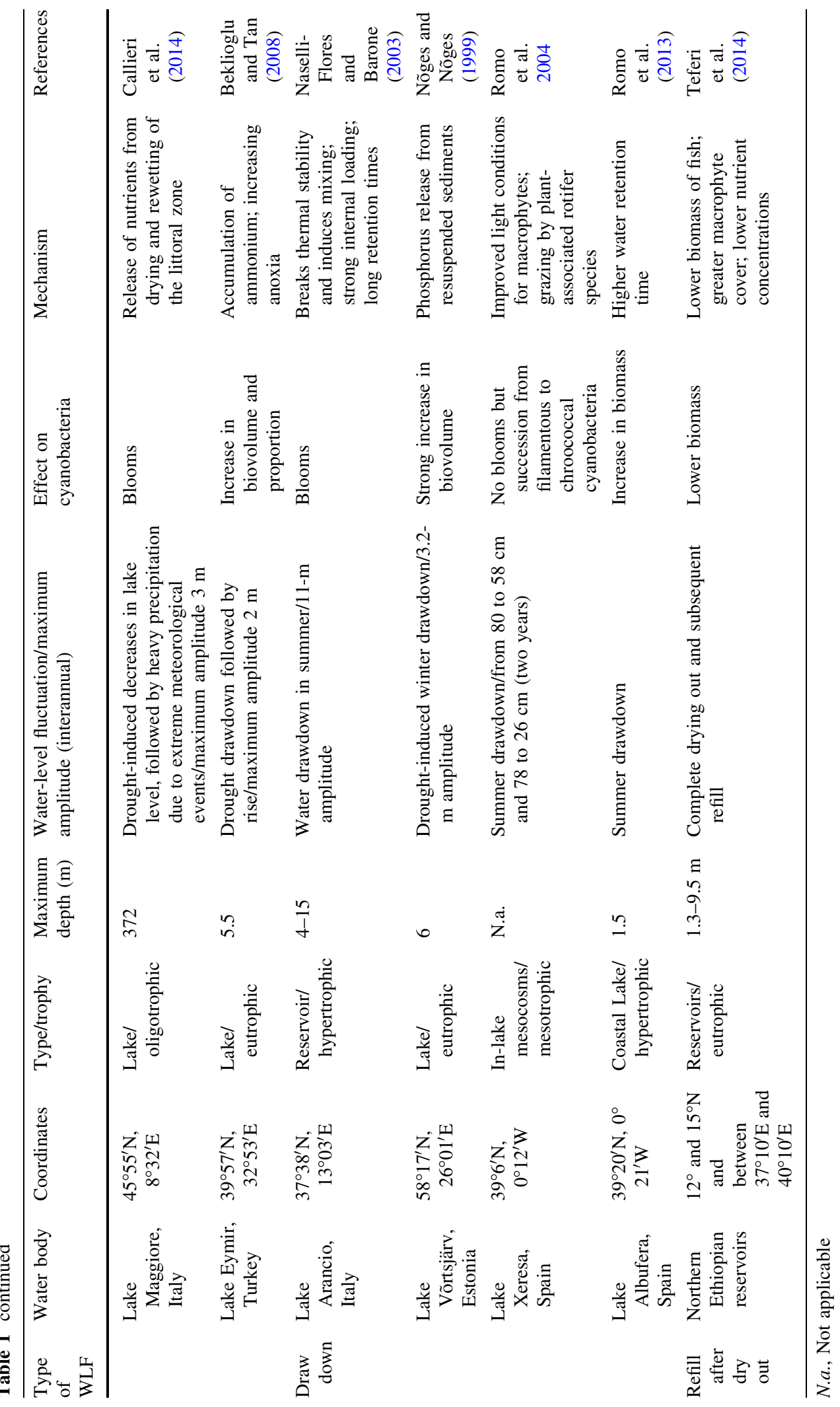


water depth, and shallow water layers warm up faster than deeper water.

Under these conditions, both the biomass and relative abundance of cyanobacteria increases, which may lead to severe cyanobacterial blooms. These phenomena have been described in the Mediterranean reservoir Lake Arancio, where a summer water-level drawdown resulted in strong blooms of Microcystis $c f$. panniformis Komárek et al. and Microcystis aeruginosa (Kützing) Kützing (Naselli-Flores and Barone 2003; Table 1). Shallow Lake Albufera in Spain responded to lower water levels with one to two orders of magnitude higher biomass of $M$. aeruginosa (Romo et al. 2013; Table 1). A winter water-level drawdown in the shallow Estonian Lake Vortsjärv induced a three times higher biovolume of nitrogenfixing cyanobacteria and a mass development of Cyanonephron styloides Hickel (Nõges and Nõges 1999; Table 1).

These effects of water-level drawdown can potentially be counteracted by the response of submerged macrophytes to the lowering of the water depth: In Lake Xeresa in Spain, the abundance of charophytes increased when the water level was low, and this prevented cyanobacterial blooms even when extra nutrients were added (up till a threshold) (Romo et al. 2004). Similarly, in Turkish Lake Eymir, spring drawdown of the water level as a result of drought improved underwater light conditions under water and stimulated macrophyte development. Despite increasing cyanobacterial (M. aeruginosa, Oscillatoria sp. and Anabaena sp.) biomass over summer, the macrophyte-dominated state was retained over summer (Beklioglu and Tan 2008; Bucak et al. 2012; Table 1).

However, free floating macrophytes are not able to provide this service: In Laguna Grande, a drawdown broke the dominance of floating plants and induced a shift to cyanobacterial blooms [Planktolyngbya limnetica (Lemmermann) Komárková-Legnerová et Cronberg, Merismopedia minima Beck, Arthrospira, Anabaenopsis elenkini Miller, Sphaerospermum aphanizomenoides (Forti) Zapomelová Zapomelová, Jezberová, Hrouzek, Hisem, Reháková \& Komárková] and disappearance of the macrophytes (O'Farrell et al. 2011). A summer drawdown may thus stimulate the development of both submerged macrophytes and cyanobacteria. Therefore, summer drawdown may result in cyanobacterial blooms, unless the development of submerged macrophytes can prevent this.

The outcome of this interaction between submerged macrophytes and cyanobacteria depends strongly on the trophic state of the water body: The more eutrophic, the more chance that cyanobacteria can dominate. However, also in more oligotrophic lakes, water-level drawdown may result in cyanobacterial blooms as drying and rewetting of littoral areas of oligotrophic Lake Maggiore resulted in nutrient release and subsequent cyanobacteria blooms of Dolichospermum lemmermannii (P.G.Richt.) Wacklin, L.Hoffm. \& Komárek (Callieri et al. 2014; Table 1).

Furthermore, the balance between macrophyte or cyanobacterial dominance is influenced by temperature and may thus vary with latitude. In the temperate Lakes Peipsi and Võrtsjärv in Estonia and the Swedish Lakes Tåkern and Krankesjön, a lowering of the water level led to dominance of submerged macrophytes, and there was very little algal development (Blindow et al. 1993; Nõges and Nõges 1999; Kangur et al. 2003). In the Mediterranean Lakes, Xeresa and Eymir cyanobacterial biomass increased, but macrophyte development prevented cyanobacterial blooms (Romo et al. 2004; Beklioglu and Tan 2008). In the subtropical floodplain lake, strong cyanobacterial blooms developed during drawdown, whereas no submerged plant development was present and floating macrophytes disappeared (O'Farrell et al. 2011). Whereas latitudinal comparisons of the effect of water drawdown may be confounded by differences in trophic state among lakes of different latitudes, with lower latitudinal lakes being more eutrophic, an increased chance of cyanobacterial blooms at higher temperatures is in general still to be expected.

There is a strong difference between the effect of a drawdown or drying out of lakes and reservoirs. Whereas a drawdown in summer stimulates growth and abundance of cyanobacteria, a complete drying out has the opposite effect. When lakes and reservoirs are refilling after drying out, they have a higher transparency and higher cover of submerged plants, as a result of germination and re-establishment, compared to lakes and reservoirs that did not dry out (Van Geest et al. 2005; Teferi et al. 2014). Northern Ethiopian reservoirs did have lower nutrient concen- 
trations, a lower fish biomass and a lower abundance of cyanobacteria (Microcystis sp.) when they had been dry (Table 1).

Drying out does not result in enhanced water column nutrient concentrations as there is no internal loading. In fact, phosphorus binds to the sediment under aerobic conditions, and therefore, there is a net phosphorous retention, instead of release, under completely dry conditions (Smolders et al. 2006; Søndergaard et al. 2013). Rewetted fens, however, show opposite patterns. Elevated levels of P release rates and $\mathrm{P}$ concentrations in pore water of up to three orders of magnitude larger than under natural reference conditions were found in rewetted fens whose surface soil layers consisted of highly decomposed peat (Zak et al. 2010). The fish biomass is strongly reduced after drying out, resulting in less sediment disturbance and less predation of zooplankton and thus higher grazing pressure on phytoplankton (Teferi et al. 2014).

Water-level rise as response to flooding has contrasting effects on the abundance of cyanobacteria. Lake Kinneret in Israel experienced its biggest ever bloom of invasive, nitrogen-fixing cyanobacteria in 1994 [Aphanizomenon ovalisporum (Forti)] and 2005 [Cylindrospermopsis raciborskii (Woloszynska) Seenayya et Subba Raju] after exceptional water-level rises (Zohary and Ostrovsky 2011; Table 1). In the Estonian Lake Peipsi, flooding led to a reduction in light availability and thus in abundance of submerged macrophytes, whereas the biomass of large nitrogenfixing Aphanizomenon flos-aquae (L.) Ralfs increased (Kangur et al. 2003). In the lower Dutch river Rhine, winter flooding with river water high in nutrients resulted in cyanobacterial (A. flos-aquae) blooms in floodplain lakes (Van den Brink et al. 1993; Table 1).

On the contrary, shallow Lake Sakadaš in the Danube valley shifted from the turbid to the clear state after extended flooding (Mihaljevic et al. 2010; Table 1). During flooding, macrophytes appeared throughout the entire floodplain, which was associated with clear water and a strong reduction in the biomass of Limnothrix redekei (Van Goor) Meffert, Planktothrix agardhii (Gom.) Anagn.et Komárek, and Pseudanabaena limnetica (Lemm.). In a small eutrophic temperate lake in Germany, flooding resulted in a fivefold increase in dissolved organic carbon and pelagic phytoplankton concentrations due to stronger thermal stratification and anoxia-driven phosphorus release from sediments
(Brothers et al. 2014). However, in an Italian reservoir, water-level rise diluted the cyanobacterial biomass and decreased retention times reduced nutrient concentrations as a result of internal loading (Naselli-Flores and Barone 2003). Therefore, the effect of water-level rise depends strongly on the effect of flooding on water nutrient concentrations and transparency.

\section{Shifts in cyanobacteria species composition in response to water-level fluctuations}

Apart from affecting the abundance of cyanobacteria, water-level fluctuations also induce shifts in the abundance of functional groups (Nõges and Nõges 1999; Romo et al. 2004). The drivers of these shifts include alterations in the availability of resources for cyanobacteria growth (nutrients and light) as well as the intensity of grazing pressure as a consequence of water-level fluctuations.

During a drawdown, internal phosphorus loading can result in a reduction in the N/P ratio in the water column nutrient concentrations. In several lakes, it has been observed that this led to both an absolute and relative increase in $\mathrm{N}_{2}$-fixing cyanobacteria, such as Aphanizomenon skujae Komárková-Legnerová et Cronberg in the Estonian Lake Võrtsjärv (Nõges and Nõges 1999; Nõges et al. 2003) and P. limnetica (Lemmermann) Komárková-Legnerová et Cronberg in the Argentinian Laguna Grande (O'Farrell et al. 2011) during drawdown.

Also, low light availability results in the dominance of shade-tolerant cyanobacteria which would be outcompeted by other phytoplankton groups under high irradiance in clear water conditions (Nõges and Nõges 1999; Nõges et al. 2003). This can be seen when water-level rise reduces light availability in the water column such as in Lake Võrtsjärv which resulted in blooms of the shade-tolerant L. redekei (Van Goor) Meffert (Nõges et al. 2003), whereas when water-level rise results in clear water conditions, such as in the Croatian Lake Sakadaš, the same species declines (Mihaljevic et al. 2010).

Furthermore, zooplankton grazing pressure affects the composition of the cyanobacterial community. When fish is (temporary) absent, as a result of fish kills during drawdown in winter or as a result of complete drying out, large zooplankton grazing pressure reduces the amount of unicellular cyanobacteria and 
phytoplankton and induces dominance by larger filamentous cyanobacteria such as observed in the Estonian Lake Peipsi and Spanish Lake Xeresa (Kangur et al. 2003; Romo et al. 2004). However, partial winter fish kill has also been found to result in a strong reduction in crustacean biomass due to abundant young-of-the-year fish, leading to a strong increase in phytoplankton biomass during the subsequent summer (Hilt et al. 2015).

\section{Using water-level fluctuations to mitigate cyanobacterial blooms}

Based on the observations of the effect of water-level fluctuations on cyanobacterial blooms, we can now discuss the options and pitfalls to use water-level fluctuations for lake and reservoir management. We summarized the effect of water-level rise and drawdown on cyanobacteria in Fig. 1 and the main mechanisms responsible for the response of cyanobacteria to water-level fluctuations in Fig. 2.

\section{Water-level rise}

Water levels can rise at high precipitation or inflow as well as reduced outflow. Particularly in river floodplains, strong fluctuations of water levels in floodplain lakes are observed as a consequence of the water level in the rivers. Positive effects are the decreased retention time of the water, which is able to reduce and perhaps even flush out cyanobacterial blooms (Verspagen et al. 2006; Romo et al. 2013). Reduced retention times may result in reduced water nutrient concentrations due to the dilution effect and consequently reduces the amount of cyanobacteria (Fig. 2a; Romo et al. 2013). It will depend on the quality of the inlet water as well as the internal loading what the best application of water-level rise is as a management measure. Rørslett and Johansen (1996) reported positive effects of high water levels for macrophyte establishment in a Norwegian reservoir. Often, such reservoirs are devoid of macrophytes due to strong water-level fluctuations and thus lack the beneficial effects of macrophytes in reducing the abundance of cyanobacteria (Sachse et al. 2014).

Several pitfalls may jeopardize the potential positive effects of water-level rise on reducing cyanobacterial blooms. When the water quality of the inlet water is poor, e.g., with high nutrient concentrations, this increases cyanobacteria growth and the chance of blooms (Fig. 2b; Van den Brink et al. 1993). Alternatively, when achieving a water-level rise by reducing the outflow of water, for instance with a sluice, this will increase the retention time, which generally enhances cyanobacterial growth (Romo et al. 2013). Furthermore, at higher water levels, macrophyte growth may be compromised by reduced light availability. Also, in a German reservoir, rising water levels resulted in large areas of inundated plants and led to a very strong year class of roach, a major planktivorous fish, which will eventually lead to turbid conditions (Fig. 2b; Kahl et al. 2008). In tropical lakes and reservoirs, fluctuating water levels enhanced nutrient transfer which positively affected fish yields (Kolding and Van Zwieten 2012).

For application as a management tool, to avoid these pitfalls, a critical evaluation of the quality of the inlet water, the potential internal nutrient loading, and factors controlling the abundance of planktivorous fish is necessary. Also, the timing of water-level rise can influence its effect. In temperate environments with strong seasonality, negative effects of water-level rise on submerged macrophytes can be avoided by applying water-level rise outside the main macrophyte growing season. In contrast, flushing with nutrientpoor water as applied for restoring eutrophic Lake Veluwe in the Netherlands during winter periods (Hosper and Meyer 1986) could probably be more

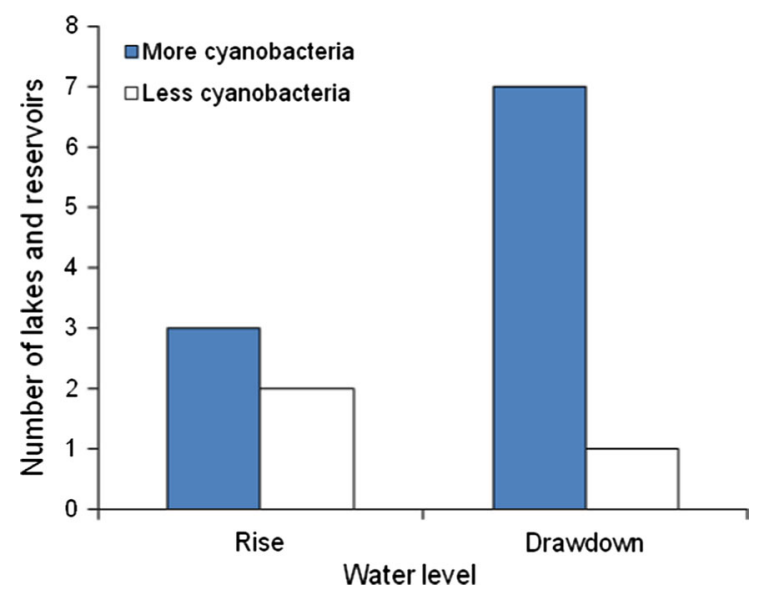

Fig. 1 Number of lakes and reservoirs with more or less cyanobacteria in response to different types of water-level fluctuation. The response of each water body is documented in Table 1 

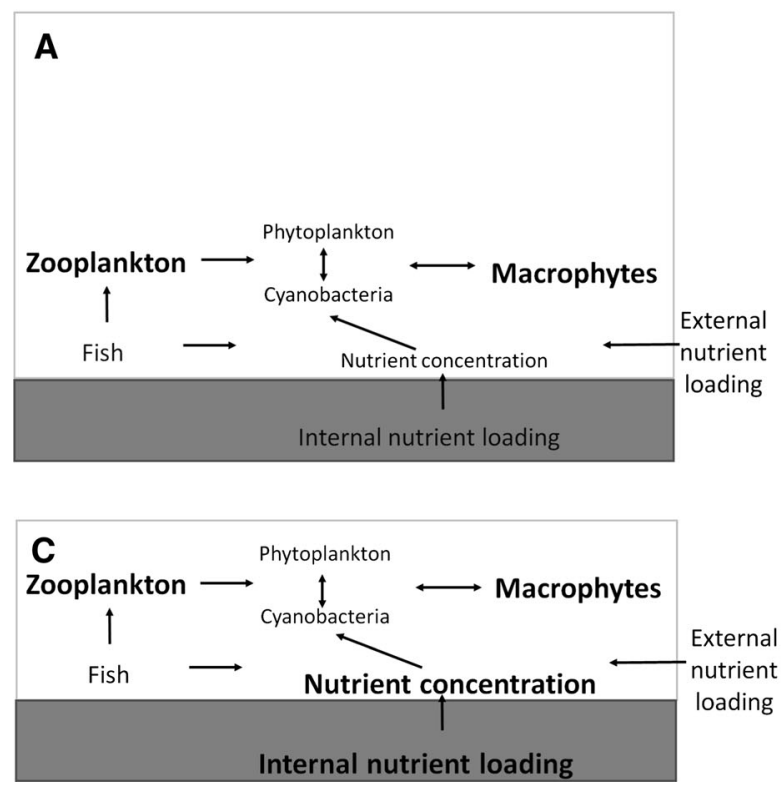

Fig. 2 Effects of water-level rise (a, b) and drawdown (c, d) on cyanobacteria abundance in shallow waters. Higher water levels were found to potentially result in lower cyanobacteria abundance due to flushing and increased macrophyte development with subsequent effects on zooplankton (a; examples: Lake Sakadaš, Laguna Grande). Opposite effects were found due to increased internal or external nutrient loading (b; examples: Lake Peipsi, Dutch floodplain lakes) or increased zooplanktivorous fish abundance (Lake Kinneret). Decreasing water levels increase the importance of internal nutrient loading in shallow waters. Under these conditions, abundant macrophytes and zooplankton may inhibit cyanobacterial blooms,

effective in spring or summer due to the direct positive influence on the interaction between submerged macrophytes and turbidity in addition to nutrient export (Hilt et al. 2011).

\section{Water-level drawdown}

Water-level drawdown occurs when water loss exceeds the inflow. Water loss can occur when the outflow exceeds the inflow, when evaporation exceeds precipitation and when water infiltration exceeds seepage, or a combination of these factors. A drawdown results in an increased retention time and a larger influence of the internal processes. Both will stimulate cyanobacterial growth, and blooms have been reported to occur after drawdowns (Cooke 1980). In addition, drawdowns in deep lakes and reservoirs in summer may reduce their macrophyte-covered area (Rørslett 1984) and consequently reduce their hampering effects on cyanobacteria (Sachse et al. 2014). On the

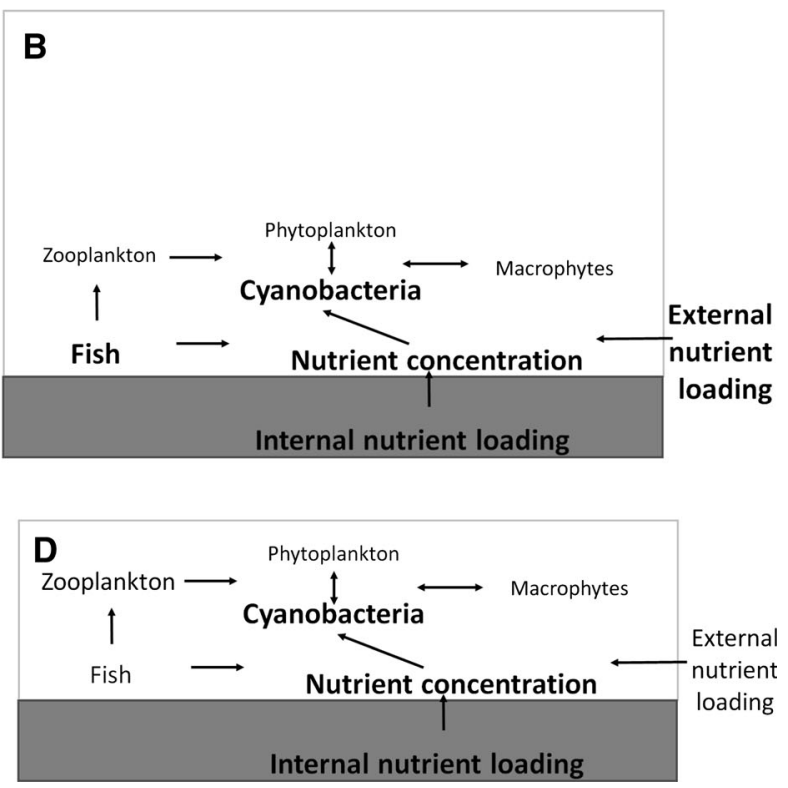

particularly after complete drying out, when fish abundance is low and nutrients are bound in the sediment (c; example: Northern Ethiopian reservoirs). In most cases when there is no complete drying out, a drawdown supports cyanobacteria abundance due to increased internal nutrient loading (d; examples: Lakes Arancio, Albufera, Maggiore). Due to contrasting effects of water-level fluctuations on the ecosystem properties, it is also possible that the net effect on cyanobacteria is neutral (not depicted in the figure). For more examples, see Table 1. The size of the text indicates the abundance of the parameter of interest

other hand, a positive effect was reported when water levels were decreased shortly after the spawning period of roach in a German reservoir, because it resulted in a total loss of the new roach year class (Kahl et al. 2008). In shallow lakes and reservoirs, the development of submerged macrophytes can be stimulated due to an improved light climate. Overall, it will strongly depend on the lake depth and morphometry, timing and extend of the drawdown, and interaction between the macrophytes and the cyanobacteria if a drawdown leads to reduced or increased cyanobacterial blooms (Fig. 2c, d).

A potential pitfall is that the positive effects of the measure depend strongly on the development of submerged macrophyte vegetation. Therefore, it is important that enough propagules or nearby sanctuaries are present to allow for the macrophytes to develop (Bakker et al. 2013). Planting of macrophytes might be considered in cases of insufficient propagules (Hilt et al. 2006). Timing of drawdown will strongly 
mitigate its effects: When applied at the start of the macrophyte growing season, the submerged macrophytes can profit optimally from the drawdown, as establishment is a sensitive step in macrophyte development. Drawdown in winter exposes parts of the sediment to both freezing and loss of water which can have strongly negative effects on aquatic plants that have no overwintering structures. It was thus recommended as a management option for nuisance macrophyte growth (Cooke 1980).

Another constraint of the success of drawdown is that the impact of benthivorous fish will increase when water volume is reduced during a drawdown. High fish activity will jeopardize the successful development of submerged vegetation and can enhance nutrient availability in the water column. Water drawdown measures thus may have to be accompanied by a strong reduction in benthic fish through biomanipulation (Meijer et al. 1990).

Also at high sediment nutrient levels, a reduction in water volume may lead to very high nutrient concentrations in the water column, which may favor the development of cyanobacteria over macrophytes as the former are growing faster, and the latter may get covered in dense periphyton layers (Fig. 2d). Furthermore, strong nutrient release of the sediment alters the $\mathrm{N} / \mathrm{P}$ ratio of available nutrients, as particularly $\mathrm{P}$ is released from the sediment. This may stimulate the development of $\mathrm{N}$-fixing cyanobacteria or mat-forming benthic cyanobacteria on sediments with a high P-loading (Nõges et al. 2003).

The success of drawdown as a management measure to mitigate cyanobacterial blooms will also depend strongly on the water temperature. Higher temperatures will favor cyanobacterial growth, and shallower water leads to higher temperatures and potentially increased cyanobacterial growth. Therefore, in warmer regions, drawdown may have less positive effects than in colder regions. Furthermore, during drawdown in Mediterranean regions, the salinity of the water increases, which alters the community composition of the aquatic organisms (Beklioglu et al. 2007).

\section{Temporary drying out}

An extreme form of a water drawdown is complete drying out. Temporary drying out for several months has a strong positive effect on reducing or preventing the occurrence of cyanobacterial blooms. The pitfalls that are associated with drawdown are largely avoided with this measure, as complete drying out will lead to fish kills eliminating the negative effects of benthivorous fish on macrophytes due to sediment resuspension and bioturbation. Furthermore, phosphorus is retained under aerobic conditions instead of released, resulting in a net reduction in internal nutrient loading. Furthermore, drying out can stimulate macrophyte recruitment, both of submerged and emergent species (Van Geest et al. 2007; Sarneel et al. 2014a; Van Leeuwen et al. 2014). Altogether, strong positive effects of drying out are documented both on the development of macrophyte vegetation and on the prevention of cyanobacterial blooms in shallow water bodies (Fig. 2c). Furthermore, these effects are prolonged, and the effects last for multiple years (Van Geest et al. 2007; Teferi et al. 2014).

Potential pitfalls are that the results of drying out may depend on the sediment characteristics. Nutrient release from drying and rewetting of lake shores has been associated with increasing cyanobacteria blooms in oligotrophic Lake Maggiore (Callieri et al. 2014). Particularly in organic soils, the biogeochemistry of nutrient exchange between the sediment and water column can be complex, and the resulting nutrient concentrations in the water column after drying out and rewetting on these soils may not be straightforward (Smolders et al. 2006; Lamers et al. 2015). Furthermore, exposure of peaty soil during drawdown or drying out may result in the burning of peat and fast decomposition. This may result in shoreline erosion, particularly when the shores have steep slopes. This would for instance apply to fens that originate from peat excavation activities (Gulati and Van Donk 2002). In contrast, nutrient fluxes from rewetted emergent plants added little to the reservoir-wide internal loading when sufficient iron supply guaranteed an efficient $P$ retention in the sediments (Kleeberg and Heidenreich 2004).

Another potential pitfall is that drying out may eliminate undesirable high densities of benthivorous and planktivorous fish, but also valuable fish species (Beklioglu et al. 2007). In the end, prolonged drying out may cause the aquatic system to be converted to a terrestrial one which has negative effects on purely aquatic vegetation (Veen et al 2013; Sarneel et al 2014b). Furthermore, little is known about the longevity of propagules of submerged macrophytes; hence, 
the feasibility of germination of submerged vegetation from the propagule bank after prolonged dry conditions is uncertain (Bakker et al. 2013). In deep regulated lakes, drying out of littoral areas may result in a compressed vertical niche for macrophytes, and often, reservoirs lack macrophytes, which reduces the potential benefit of drying out (Rørslett 1984; Rørslett and Johansen 1996).

\section{Morphometry of the water body}

The results of water-level fluctuation management will depend strongly on the geometry of the water body. Water-level fluctuations will have a much stronger impact on shallow water bodies then on deep ones, when the range of fluctuations is equal (Sarneel et al 2014b). Also, the slope of the shoreline will strongly mitigate the effect of water-level fluctuations. Shallow water bodies with shallow slopes will experience large impact of water-level fluctuations, whereas deep water bodies with steep shores may be hardly affected (Nowlin et al. 2004).

Furthermore, the lake or reservoir depth can affect whether there is stratification. When water-level fluctuations do not result in mixing of the water layers, then the effect may be limited. However, when water-level fluctuations result in a breaking up of stratification, then the impact can be much stronger due to an increased nutrient availability in the upper part of the water column as a result of mixing of the water layers (Naselli-Flores and Barone 2003; Zohary and Ostrovsky 2011). This in turn may stimulate the growth of cyanobacteria, enhancing the chance of a cyanobacterial bloom. However, mixing can also prevent cyanobacteria blooms (Visser et al. 1996), whereas stronger stratification can also support cyanobacteria blooms (Wagner and Adrian 2009).

\section{Conclusions}

Management of water-level fluctuations has not been used yet to particularly mitigate cyanobacterial blooms. Based on our exploration of case studies in the literature, we conclude that it is in principle possible to do this. A water-level drawdown will only reduce cyanobacteria blooms when accompanied by a strong increase in submerged macrophyte abundance, which subsequently compete for nutrients with cyanobacteria or when it leads to a complete drying out. Chances for these effects are likely to be higher in shallow lakes or in reservoirs when fully emptied. In deep lakes and reservoirs, decreasing water levels (without complete drying out) have only been reported to result in cyanobacteria blooms. Water-level rises as response to flooding were found to have contrasting effects on the abundance of cyanobacteria in shallow and deep lakes and reservoirs.

Overall, the outcome of a certain regime of waterlevel fluctuations will depend strongly on the local conditions, including lake or reservoir depth and morphometry, sediment type, water retention time, quality of inlet water, presence of submerged vegetation or propagules thereof, abundance of benthivorous and planktivorous fish, and climate zone. When these are known, it is possible to estimate the benefits and risks of water-level management as a measure to mitigate cyanobacterial blooms.

Open Access This article is distributed under the terms of the Creative Commons Attribution 4.0 International License (http:// creativecommons.org/licenses/by/4.0/), which permits unrestricted use, distribution, and reproduction in any medium, provided you give appropriate credit to the original author(s) and the source, provide a link to the Creative Commons license, and indicate if changes were made.

\section{References}

Adrian R, O’Reilly CM, Zagarese H, Baines SB, Hessen DO, Keller W, Livingstone DM, Sommaruga R, Straile D, Van Donk E, Weyhenmeyer GA, Winder M (2009) Lakes as sentinels of climate change. Limnol Oceanogr 54:22832297

Bakker ES, Van Donk E, Declerck SAJ, Helmsing NR, Hidding B, Nolet BA (2010) Effect of macrophyte community composition and nutrient enrichment on plant biomass and algal blooms. Basic Appl Ecol 11:432-439

Bakker ES, Sarneel JM, Gulati RD, Liu Z, Van Donk E (2013) Restoring macrophyte diversity in shallow temperate lakes: biotic versus abiotic constraints. Hydrobiologia 710:23-37

Beklioglu M, Tan CO (2008) Restoration of a shallow Mediterranean lake by biomanipulation complicated by drought. Fundam Appl Limnol 171:105-118

Beklioglu M, Romo S, Kagalou I, Quintana X, Becares E (2007) State of the art in the functioning of shallow Mediterranean lakes: workshop conclusions. Hydrobiologia 584:317-326

Blindow I, Andersson G, Hargeby A, Johansson S (1993) Longterm pattern of alternative stable states in 2 shallow eutrophic lakes. Freshw Biol 30:159-167 
Blindow I, Hargeby A, Hilt S (2014) Facilitation of clear-water conditions in shallow lakes by macrophytes: differences between charophyte and angiosperm dominance. Hydrobiologia 737:99-110

Brothers S, Köhler J, Meyer N, Attermeyer K, Grossart HP, Mehner T, Scharnweber K, Hilt S (2014) A feedback loop links brownification and anoxia in a temperate, shallow lake. Limnol Oceanogr 59:1388-1398

Bucak T, Saraoglu E, Levi E, Tavsanoglu UN, Cakiroglu AI, Jeppesen E, Beklioglu M (2012) The influence of water level on macrophyte growth and trophic interactions in eutrophic Mediterranean shallow lakes: a mesocosm experiment with and without fish. Freshw Biol 57:16311642

Burks RL, Jeppesen E, Lodge DM (2001) Littoral zone structures as Daphnia refugia against fish predators. Limnol Oceanogr 46:230-237

Callieri C, Bertoni R, Contesini M, Bertoni F (2014) Lake level fluctuations boost toxic cyanobacterial "Oligotrophic Blooms". PLoS ONE 9(10):e109526

Chang X, Eigemann F, Hilt S (2012) Do macrophytes support harmful cyanobacteria? Interactions with a green alga reverse the inhibiting effects of macrophyte allelochemicals on Microcystis aeruginosa. Harmful Algae 19:76-84

Cooke CD (1980) Lake level drawdown as a macrophyte control technique. Water Resour Bull 16:317-322

Coops H, Hosper SH (2002) Water-level management as a tool for the restoration of shallow lakes in the Netherlands. Lake Reserv Manag 18:293-298

Coops H, Beklioglu M, Crisman TL (2003) The role of waterlevel fluctuations in shallow lake ecosystems-workshop conclusions. Hydrobiologia 506:23-27

Dong J, Yang K, Li S, Li G, Song L (2014) Submerged vegetation removal promotes shift of dominant phytoplankton functional groups in a eutrophic lake. J Environ Sci 26:1699-1707

Eigemann F, Vanormelingen P, Hilt S (2013) Sensitivity of the green alga Pediastrum duplex Meyen to allelochemicals is strain-specific and not related to co-occurrence with allelopathic macrophytes. PLoS ONE 8(10):e78463

Ejankowski W, Solis M (2015) Response of hornwort (Ceratophyllum demersum) to water level drawdown in a turbid water reservoir. Appl Ecol Environ Res 13:219-228

Gross EM (2003) Allelopathy of aquatic autotrophs. Crit Rev Plant Sci 22:313-339

Grutters BMC, Pollux BJA, Verberk WCEP, Bakker ES (2015) Native and non-native plants provide similar refuge to invertebrate prey, but less than artificial plants. PLoS ONE 10:e0124455

Gulati RD, Van Donk E (2002) Lakes in the Netherlands, their origin, eutrophication and restoration: state-of-the-art review. Hydrobiologia 478:73-106

Havens KE, Sharfstein B, Brady MA, East TL, Harwell MC, Maki RP, Rodusky AJ (2004) Recovery of submerged plants from high water stress in a large subtropical lake in Florida, USA. Aquat Bot 78:67-82

Hilt S, Gross EM (2008) Can allelopathically active submerged macrophytes stabilise clear-water states in shallow lakes? Basic Appl Ecol 9:422-432

Hilt S, Gross EM, Hupfer M, Morscheid H, Mählmann J, Melzer A, Poltz J, Sandrock S, Scharf EM, Schneider S, Van de
Weyer K (2006) Restoration of submerged vegetation in shallow eutrophic lakes: guideline and state of the art in Germany. Limnologica 36:155-171

Hilt S, Henschke I, Rücker J, Nixdorf B (2010) Can submerged macrophytes influence turbidity and trophic state in deep lakes? Suggestions from a case study. J Environ Qual 39:725-733

Hilt S, Köhler J, Kozerski HP, Scheffer M, Van Nes E (2011) Abrupt regime shifts in space and time along rivers and connected lakes systems. Oikos 120:766-775

Hilt S, Wanke T, Brauns M, Brothers S, Gaedke U, Köhler J, Lischke B, Syväranta J, Scharnweber K, Mehner T (2015) Contrasting response of shallow eutrophic lakes to winterkill of fish. Hydrobiologia 749:31-42

Holm TE, Clausen P (2006) Effects of water level management on autumn staging waterbird and macrophyte diversity in three Danish coastal lagoons. Biodivers Conserv 15:4399-4423

Hosper H, Meyer M-L (1986) Control of phosphorus loading and flushing as restoration methods for Lake Veluwe, the Netherlands. Hydrobiol Bull 20:183-194

IPCC (2007) Climate change 2007: synthesis report. IPCC, Geneva

Jeppesen E, Søndergaard M, Søndergaard M, Christoffersen K (eds) (1998) The structuring role of submerged macrophytes in lakes. Ecological Studies. Springer, New York

Jeppesen E, Meerhoff M, Davidson TA, Trolle D, Søndergaard M, Lauridsen TL, Beklioglu M, Brucet S, Volta P, Gonzalez-Bergonzoni I, Nielsen A (2014) Climate change impacts on lakes: an integrated ecological perspective based on a multi-faceted approach, with special focus on shallow lakes. J Limnol 73:88-111

Kahl U, Hülsmann S, Radke RJ, Benndorf J (2008) The impact of water level fluctuations on the year class strength of roach: implications for fish stock management. Limnologica 38:258-268

Kangur K, Mols T, Milius A, Laugaste R (2003) Phytoplankton response to changed nutrient level in Lake Peipsi (Estonia) in 1992-2001. Hydrobiologia 506:265-272

Kleeberg A, Heidenreich M (2004) Release of nitrogen and phosphorus from macrophyte stands of summer dried out sediments of a eutrophic reservoir. Arch Hydrobiol 159:115-136

Kolding J, Van Zwieten PAM (2012) Relative lake level fluctuations and their influence on productivity and resilience in tropical lakes and reservoirs. Fish Res 115-116:99-109

Kosten S, Lacerot G, Jeppesen E, Marques DD, Van Nes EH, Mazzeo N, Scheffer M (2009) Effects of submerged vegetation on water clarity across climates. Ecosystems 12:1117-1129

Kosten S, Huszar VLM, Becares E, Costa LS, Van Donk E, Hansson LA, Jeppesen E, Kruk C, Lacerot G, Mazzeo N, De Meester L, Moss B, Lürling M, Nõges T, Romo S, Scheffer M (2012) Warmer climates boost cyanobacterial dominance in shallow lakes. Glob Change Biol 18:118-126

Lamers LPM, Vile MA, Grootjans AP, Acreman MC, Van Diggelen R, Evans MG, Richardson CJ, Rochefort L, Kooijman AM, Roelofs JGM, Smolders AJP (2015) Ecological restoration of rich fens in Europe and North 
America: from trial and error to an evidence-based approach. Biol Rev 90:182-203

Liu BY, Jiang P, Zhou AE, Tian JR, Jiang SY (2007) Effect of pyrogallol on the growth and pigment content of cyanobacteria-blooming toxic and nontoxic Microcystis aeruginosa. Bull Environ Contam Toxicol 78:499-502

Mahdy A, Scharfenberger U, Adrian R, Hilt S (2015) Experimental comparison of periphyton removal rates by chironomid larvae and Daphnia magna. Inland Waters 5:81-88

Meijer ML, DeHaan MW, Breukelaar AW, Buiteveld H (1990) Is reduction of the benthivorous fish an important cause of high transparency following biomanipulation in shallow lakes. Hydrobiologia 200:303-315

Mihaljevic M, Spoljaric D, Stevic F, Cvijanovic V, Kutuzovic BH (2010) The influence of extreme floods from the River Danube in 2006 on phytoplankton communities in a floodplain lake: shift to a clear state. Limnologica 40:260-268

Mjelde M, Faafeng BA (1997) Ceratophyllum demersum hampers phytoplankton development in some small Norwegian lakes over a wide range of phosphorus concentrations and geographical latitude. Freshw Biol 37:355-365

Mooij WM, Hülsmann S, Desenerpont Domis LN, Nolet BA, Bodelier PLE, Boers PCM, Dionisio Pires LM, Gons HJ, Ibelings BW, Noordhuis R, Portielje R, Wolfstein K, Lammens $E$ (2005) The impact of climate change on lakes in the Netherlands: a review. Aquat Ecol 39:381-400

Mulderij G, Mooij WM, Smolders AJP, Van Donk E (2005) Allelopathic inhibition of phytoplankton by exudates from Stratiotes aloides. Aquat Bot 82:284-296

Naselli-Flores L, Barone R (2003) Steady-state assemblages in a Mediterranean hypertrophic reservoir. The role of Microcystis ecomorphological variability in maintaining an apparent equilibrium. Hydrobiologia 502:133-143

Nõges T, Nõges P (1999) The effect of extreme water level decrease on hydrochemistry and phytoplankton in a shallow eutrophic lake. Hydrobiologia 408:277-283

Nõges T, Nõges P, Laugaste R (2003) Water level as the mediator between climate change and phytoplankton composition in a large shallow temperate lake. Hydrobiologia 506:257-263

Nowlin WH, Davies JM, Nordin RN, Mazumder A (2004) Effects of water level fluctuation and short-term climate variation on thermal and stratification regimes of a British Columbia reservoir and lake. Lake Reserv Manag 20:91-109

O'Farrell I, Izaguirre I, Chaparro G, Unrein F, Sinistro R, Pizarro H, Rodriguez P, Pinto PD, Lombardo R, Tell G (2011) Water level as the main driver of the alternation between a free-floating plant and a phytoplankton dominated state: a long-term study in a floodplain lake. Aquat Sci 73:275-287

Paerl HW, Huisman J (2008) Climate: blooms like it hot. Science 320:57-58

Paerl HW, Huisman J (2009) Climate change: a catalyst for global expansion of harmful cyanobacterial blooms. Environ Microbiol Rep 1:27-37

Romo S, Miracle MR, Villena MJ, Rueda J, Ferriol C, Vicente E (2004) Mesocosm experiments on nutrient and fish effects on shallow lake food webs in a Mediterranean climate. Freshw Biol 49:1593-1607
Romo S, Soria J, Fernandez F, Ouahid Y, Baron-Sola A (2013) Water residence time and the dynamics of toxic cyanobacteria. Freshw Biol 58:513-522

Rørslett B (1984) Environmental factors and aquatic macrophyte response in regulated lakes: a statistical approach. Aquat Bot 19:199-220

Rørslett B, Johansen SW (1996) Remedial measures connected with aquatic macrophytes in Norwegian regulated rivers and reservoirs. Regul Rivers 12:509-522

Rueda F, Moreno-Ostos E, Armengol J (2006) The residence time of river water in reservoirs. Ecol Model 191:260-274

Sachse R, Petzoldt T, Blumstock M, Moreira Martinez S, Pätzig M, Rücker J, Janse J, Mooij WM, Hilt S (2014) Extending one-dimensional models for deep lakes to simulate the impact of submerged macrophytes on water quality. Environ Model Softw 61:410-423

Sarneel JM, Janssen RH, Rip WJ, Bender IMA, Bakker ES (2014a) Windows of opportunity for germination of riparian species after restoring water level fluctuations: a field experiment with controlled seed banks. J Appl Ecol 51:1006-1014

Sarneel JM, Huig N, Veen GF, Rip W, Bakker ES (2014b) Herbivores enforce sharp boundaries between terrestrial and aquatic ecosystems. Ecosystems 17:1426-1438

Scheffer M (1998) Ecology of shallow lakes. Chapman \& Hall, London

Schriver P, Bogestrand J, Jeppesen E, Søndergaard M (1995) Impact of submerged macrophytes on fish-zooplankton interactions: large-scale enclosure experiments in a shallow eutrophic lake. Freshw Biol 33:255-270

Shao J, Li R, Lepo JE, Gu JD (2013) Potential for control of cyanobacterial blooms using bioactive substances: problems and prospects. J Environ Manag 125:149-155

Smolders AJP, Lamers LPM, Lucassen E, Van der Velde G, Roelofs JGM (2006) Internal eutrophication: how it works and what to do about it: a review. Chem Ecol 22:93-111

Søndergaard M, Bjerring R, Jeppesen E (2013) Persistent internal phosphorus loading during summer in shallow eutrophic lakes. Hydrobiologia 710:95-107

Švanys A, Paškauskas R, Hilt S (2014) Effects of the allelopathically active macrophyte Myriophyllum spicatum on a natural phytoplankton community: a mesocosm study. Hydrobiologia 737:57-66

Teferi M, Declerck SAJ, De Bie T, Lemmens P, Gebrekidan A, Asmelash T, Dejenie T, Gebrehiwot K, Bauer H, Deckers JA, Snoeks J, De Meester L (2014) Strong effects of occasional drying on subsequent water clarity and cyanobacterial blooms in cool tropical reservoirs. Freshw Biol 59:870-884

Van den Brink FWB, De Leeuw JPHM, Van der Velde G, Verheggen GM (1993) Impact of hydrology on the chemistry and phytoplankton development in floodplain lakes along the Lower Rhine and Meuse. Biogeochemistry 19:103-128

Van Donk E, Van de Bund WJ (2002) Impact of submerged macrophytes including charophytes on phyto- and zooplankton communities: allelopathy versus other mechanisms. Aquat Bot 72:261-274

Van Geest GJ, Coops H, Roijackers RMM, Buijse AD, Scheffer M (2005) Succession of aquatic vegetation driven by 
reduced water-level fluctuations in floodplain lakes. J Appl Ecol 42:251-260

Van Geest GJ, Coops H, Scheffer M, Van Nes EH (2007) Long transients near the ghost of a stable state in eutrophic shallow lakes with fluctuating water levels. Ecosystems 10:37-47

Van Leeuwen CHA, Sarneel JM, Van Paassen J, Rip WJ, Bakker ES (2014) Hydrology, shore morphology and species traits affect seed dispersal, germination and community assembly in shoreline plant communities. J Ecol 102:998-1007

Veen GF, Sarneel JM, Ravensbergen L, Huig N, Van Paassen J, Rip W, Bakker ES (2013) Aquatic grazers reduce the establishment and growth of riparian plants along an environmental gradient. Freshw Biol 58:1794-1803

Verspagen JMH, Passarge J, Johnk KD, Visser PM, Peperzak L, Boers P, Laanbroek HJ, Huisman J (2006) Water management strategies against toxic Microcystis blooms in the Dutch delta. Ecol Appl 16:313-327

Visser PM, Ibelings BW, Van der Veer B, Koedood J, Mur LR (1996) Artificial mixing prevents nuisance blooms of the cyanobacterium Microcystis in Lake Nieuwe Meer, the Netherlands. Freshw Biol 36:435-450
Wagner C, Adrian R (2009) Cyanobacteria dominance: quantifying the effects of climate change. Limnol Oceanogr 54:2460-2468

Wantzen KM, Rothhaupt K-O, Moertl M, Cantonati M, Toth LG, Fischer P (2008) Ecological effects of water-level fluctuations in lakes: an urgent issue. Hydrobiologia 613:1-4

Welch EB (1981) The dilution/flushing technique in lake restoration. JAWRA 17:558-564

Williamson CE, Saros JE, Vincent WF, Smol JP (2009) Lakes and reservoirs as sentinels, integrators, and regulators of climate change. Limnol Oceanogr 54:2273-2282

Zak D, Wagner C, Payer B, Augustin J, Gelbrecht J (2010) Phosphorus mobilization in rewetted fens: the effect of altered peat properties and implications for their restoration. Ecol Appl 20:1336-1349

Zohary T, Ostrovsky I (2011) Ecological impacts of excessive water level fluctuations in stratified freshwater lakes. Inland Waters 1:47-59 